\title{
Epidemiological characteristics of non-melanoma skin cancer in Indonesia: preliminary results
}

Setyawati Budiningsih ${ }^{1}$, Joede Prihartono' ${ }^{1}$ Yoshiyuki Ohno ${ }^{2}$, Mochtar Hamzah ${ }^{3}$, Masamitsu Ichihashi ${ }^{4}$, Santoso Cornain ${ }^{5}$, Masato Ueda ${ }^{4}$, Mpu Kanoko $^{5}$, Arman Mukhtar ${ }^{6}$, Ahmad Tjarta ${ }^{5}$, Evert Poetiray ${ }^{6}$, Nobuo Munakata ${ }^{7}$, Herman Cipte $^{3}$

\begin{abstract}
Abstrak
Kanker kulit non-melanoma merupakan jenis yang terbanyak terjadi diberbagai negara. Pada studi kasus- kontrol yang dilakukan di Rumah Sakit Umum Pusat Nasional Dr. Cipto Mangunkusumo, Jakarta, dengan 139 kasus kanker kulit, distribusi pada wanita dan pria tidak menunjukkan perbedaan bermakna. Sebagian besar (75\%) kasus berlatar belakang pendidikan rendah. Tingkat pendidikan menunjukkan hubungan yang bermakna dengan pajanan terhadap rokok, kebiasaan memakai lengan panjang dan konsumsi tinggi lemak, protein dan sayuran. Jenis pekerjaan di luar gedung berhubungan dengan pendidikan yang lebih rendah dan konsumsi sayuran dan buah yang lebih rendah, sedangkan pekerjaan di dalam gedung berhubungan dengan pendidikan menengah keatas dan konsumsi tinggi sayuran dan buah yang lebih tinggi. Khusus untuk kelompok yang berpendidikan sekolah menengah keatas, dengan uji kecenderungan terlihat adanya kecenderungan yang sangat bermakna. Terlihat bahwa makin tinggi pendidikan maka risiko dari pajanan berbagai faktor diatas menjadi lebih rendah. Dilihat dari jenis kanker kulit, karsinoma sel basal (KSB) merupakan tipe terbanyak disusul oleh karsinoma sel skiumosa (KSS). Secara epidemiologis terihat bahwa KSB memang lebih banyak terdapat pada pria, pada yang berpendidikan rendah dan pada individu dengan jenis pekerjaan dan kebiasaan dengan tingkat pajanan pada sinar ultraviolet lebih tinggi. Berdasarkan uji kecenderungan, tidak terlihat adanya perbedaan yang bermakna pada kedua tipe kanker kulit, kecenderungan KSB menurut tingkat pendidikan. Hasil yang diperoleh dalam studi epidemiologi ini, memperkuat hasil-hasil yang dilaporkan oleh peneliti lain. Untuk lebih menjelaskan pengaruh beberapa faktor risiko, sedang dilakukan analisa lebih lanjut dengan pengumpulan data yang iebih besar.
\end{abstract}

\begin{abstract}
Non-melanoma in the most common type occurring in various countries. In case-control study performed at Dr. Cipto Mangunkusumo National General Hospital, Jakarta, with 139 skin cancer cases, the distribution in females and males did not show significant difference. The majority (75\%) of cases had low educaitional backoround. Educational level showed significant correlation to exposure to smoking, using long sleeve and high consumption of fat, protein and vegetables. Working outdoor associated with lower level of education and lower consumption of vegetables and fruits, while working indoor associated with higher level of education and higher consumption of vegetables and fruits. In particular for junior and high school educated individuals, the test for trend showed high significance. The higher the educutional level the lower the risk of the above mentioned factors. Basal cell carcinoma (BCC) in the most frequent type, followed by squamous cell carcinoma (SCC). Epidemiologically, BCC was folind higher among males, in lower educational level and in individuals with occupation and habit with high exposure to ultraviolet. Test for trend did not show significant difference in comparing BCC to SCC, except for the trend for BCC according to educational levels. The results obtained in this epidemiological study confirmed the results reported by others. In order to clarify the effects of several factors, further analysis using larger data is in progress.
\end{abstract}

Keywords: Epidemiology, skin cancer, non-melanoma

\footnotetext{
1 Department of Community Medicine, Faculty of Medicine, University of Indonesia, Jakarta 10320, Indonesia

${ }^{2}$ Depariment of Preventive Medicine, Nagoya University School of Medicine, Nagoya 466-8550, Japan

${ }^{3}$ Department of Dermatology, Faculty of Medicine, University of Indonesia, Jakarta 10430, Indonesia

${ }^{4}$ Department of Dermatology, Kobe University School of Medicine, Kobe 650-00I7, Japan

5 Department of Anatomic Pathology, Faculty of Medicine. University of Indonesia, Jakarta 10430, Indonesia

${ }^{6}$ Department of Surgery, Faculty of Medicine, University of Indonesia, Jakarta 10430, Indonesia

7 Radiobiology Division. National Cancer Center Research Institute, Tokyo 104-0045, Japan
}

In Indonesia, according to the nearly nation-wide data collected from 13 Pathology Laboratories by the National Cancer Registry (pathology based), the nonmelanoma skin cancer (NMSC) rank the first among males and the fourth among females in 1992. ${ }^{1}$ The relative frequency was 11.79 and 6.23 respectively. In a study conducted in Semarang (Central Java) based on a population-based cancer registry in 1988, the figures also showed high incidence for non-melanoma skin cancer, 6.67 per 100,000 among males and 6.54 
per 100,000 among females. ${ }^{2}$ Basal cell carcinoma and squamous cell carcinoma were the most common types. Epidemiologic characteristics showed that the peak age of cases was on 50-59 years $(27.1 \%)$. The most frequent site of all skin tumors were on the head and neck $(58.5 \%)$, while the rest $(27.1 \%)$ were on the extremities. ${ }^{3}$ For the malignant melanoma, the study found that incidence in males is $56.8 \%$ and $43.2 \%$ in females. The distribution of the localization is $78.3 \%$ in lower extremities in males and $54.8 \%$ in females respectively. The geographic distribution, comparing between the urban and rural, showed that the lesion on the foot was found lower in the urban area either in males and females.

There are many factors related to skin cancer, sun exposure and skin type are the most outstanding in many studies. In Japan, the incidence varied from 0.1$0.3 / 100,000$ for melanoma and 1.5-5.0 for nonmelanoma skin cancer. ${ }^{4}$ The prevalence rates of basal cell carcinoma (BCC) were 16.5 per 100,000 population. ${ }^{5}$ The study also showed that skin type 1 (burn easily, tan poorly), showed a higher risk for non-melanoma skin cancer (NMSC). The prevalence of skin cancer of outdoor workers was higher than indoors ones.

Epidemiological studies concerning skin cancer in Indonesia, had not been done extensively. However, result of Household Health Survey (1992), indicated that carcinoma was the $10^{\text {th }}$ cause of mortality. Several areas in Indonesia are located just in the equator belt with extensive sunlight exposure. As commonly occurred in developing country, most of the population used to work as farmers or having occupation with heavy sun exposure.

Based on the above reasons a multidiciplinary research (pathology, surgery, dermatology and epidemiology) was conducted from 1996 to 1999 with case-control design.

Besides the risk assessment hy comparing the cases to the controls, the epidemiological characterization of the skin cancer cases was also performed. The results of the latter will be presented in this paper.

\section{MATERIALS AND METHODS}

The study on etiology and clinicopathology of skin cancer was conducted using a case-control design with 1 to 2 ratio of case to control. Both cases and controls were collected from patients visiting the Dr.
Cipto Mangunkusumo National Central General Hospital. Population used for cases were skin cancer patient newly diagnosed in the Departments of Dermatology and Surgery. The eligible cases were the skin cancer cases collected from January 1996 to March 1999 with both clinical and histopathological diagnosis. Ail cases of skin cancer and nonmelanoma, i.e. basal cell carcinoma (BCC) and squamous cell carcinoma (SCC) were subjected to epidemiological characterization.

Population used for controls were other patients (inpatients \& outpatients) in the same departments who had been confirmed as having no skin cancer. The matching variable were age (ca $3 \mathrm{yrs}$ ), gender and socio-economic status, indicated from the type of hospital room they used or intended to used. Based on statistical calculation using several consideration, the study plan to collect 300 triplet cases. The controls were recruited within 3 months after the enrollment of the cases.

Besides clinical and pathological data, there were 4 general epidemiological characteristics collected in the study, namely demographic, health, environment and nutritional. Data were collected through 3 types, of questionnaires, clinical, pathological and epidemiological forms. Epidemiological data were collected by paramedics while the clinical and pathological data by oncologist/surgeon and pathological specialist.

The analyses included: 1) the demographic, health, environment and nutrition status among skin cancer; 2) the relationship between education and occupation with sun exposure and nutrition factors among skin cancer and 3) the difference between BCC and SCC in demographic and nutrition factors.

Chi-square, log linear regression test for trend were used to analyze the epidemiologic characteristics of skin cancer.

\section{RESULTS}

\section{Demographic characteristics}

By demographic characteristics, we refer to gender, age, education and occupation of the skin cancer patient enrolled in the study. Among 139 cases of skin cancer, female has a slight higher percentage compared to male $(56.8 \%$ vs $43.2 \%)$. More than half $(73.4 \%)$ of the patients were older than 50 years and $8.6 \%$ were less than 40 years old. About $75 \%$ of 
patients in this study had less than 6 years education, and only $12.2 \%$ graduated from junior high school. Percentage of patients with occupation outside or inside the building representing sun-exposed or nonsun exposed situation was not different $(49.6 \%$ vs $50.4 \%$ ), see Table 1 .

Table 1. Demographic characteristic of skin cancer patients

\begin{tabular}{lrr}
\hline Variable & $\mathbf{n = 1 3 9}$ & $\mathbf{\%}$ \\
\hline Gender & & \\
$\quad$ Male & 60 & 43.2 \\
$\quad$ Female & 79 & 56.8 \\
Age & & \\
$\quad<40$ years & 12 & 8.6 \\
$\quad 40-50$ years & 25 & 18.0 \\
$51-60$ years & 41 & 29.5 \\
$>60$ years & 61 & 43.9 \\
Education & 109 & 78.4 \\
$\quad$ Elementary school & 13 & 9.4 \\
$\quad$ Junior High school & 17 & 12.2 \\
$\quad$ Senior High .school & & \\
Occupation & 69 & 49.6 \\
$\quad$ Outside & 70 & 50.4 \\
$\quad$ Inside & & \\
\hline
\end{tabular}

\section{Health characteristics}

Cancer history, nutritional status, hormonal exposure and smoking habit were the health risk factors observed. Table 2 shows that $72 \%$ patients still have a normal-good nutritional status, only $18 \%$ were underweight. History of cancer was low among the skin cancer patients, only $4.6 \%$ had a relative with any cancers. Almost all of the skin cancer cases had never been exposed to hormone $(97.7 \%)$ and almost $75 \%$ of the patients did not smoke.

Table 2. Health characteristics of skin cancer patients

\begin{tabular}{lrr}
\hline Variable & $\mathbf{n = 1 3 9}$ & $\%$ \\
\hline Nutritional status & & \\
$\quad$ Underweight & 25 & 18.0 \\
$\quad$ Normal weight & 60 & 43.2 \\
Overweight & 54 & 38.8 \\
Cancer history & & \\
$\quad$ Yes & 6 & 4.6 \\
$\quad$ No & 133 & 95.4 \\
Hormonal & & \\
Yes & 3 & 2.3 \\
$\quad$ No & 136 & 97.7 \\
Smoking & & \\
Yes & 32 & 23.0 \\
Ex smoker & 22 & 2.3 \\
$\quad$ No & 68 & \\
\hline
\end{tabular}

\section{Environmental characteristics}

Environmental characteristics are referred to the exposure to cigarette and sun/ UV. Table 3 shows that almost the half $(44.6 \%)$ of cases were exposed to cigarette, $50 \%$ of them were actually the non smoker patients (Tables $1 \& 2$ ). Using hat as a protection to sun was higher than using long sleeve $(73.4 \%$ vs $42.4 \%)$.

Table 3. Environmental characteristics of skin cancer patients

\begin{tabular}{lrc}
\hline Variable & $\mathbf{n = 1 3 9}$ & $\%$ \\
\hline Exposed to cigarette & 62 & 44.6 \\
$\quad$ Yes & 77 & 55.4 \\
$\quad$ No & & \\
Used hat & 102 & 73.4 \\
$\quad$ Yes & 37 & 26.6 \\
$\quad$ No & & \\
Using long sleeve & 59 & 42.4 \\
Yes & 80 & 57.6 \\
$\quad$ No & & \\
\hline
\end{tabular}

\section{Nutritional pattern}

Nutritional pattern of food consumed by cases in the last 5 years, were related to the fat, fibre, vegetable and garlic. Milk, meat and fatty meat were not much consumed by the patients $(85.4,61.9$ and $66.2 \%$, respectively). Almost $50 \%$ of the patients received their fat from consuming coconut food (food which was cooked by using coconut milk). Vegetables as a source of fiber have not been consumed by almost $50 \%$ of cases. Garlic was assumed to have an effect in protecting against skin cancer, in this study about $40 \%$ of cases usually consumed it in their daily food (Table 4).

\section{Relationship of education and occupation to some risk factors}

By using Chi-square test, in general, Table 5 shows that except for smoking habits a significant relationship $(\mathrm{P}<0.05)$ were found between education and several factors, those were occupation, exposure to cigarette, using long sleeve, and intake of fat/ protein/ vegetable/ fruit. The test for trend in junior \& senior high school group showed a strong relationship with occupation $(\mathrm{P}<0.001)$. A very strong significant relationship also were noted between education and 
exposure to cigarette $(\mathrm{P}<0.005)$, using long sleeve $(\mathrm{P}$ $<0.001$ ), consumption of fat/ protein/ vegetable/ fruit $(\mathrm{P}<0.001)$. In the junior \& senior high school using long sleeve and consumption of vegetables/ fruits has a strong relationship $(\mathrm{P}<0.001$ and $\mathrm{P}<0.01$ ). In the elementary group the trend test showed a strong significant result only in consumption of protein.

Tabie 4. Nutritional characteristics of the skin cancer patients

\begin{tabular}{|c|c|c|c|}
\hline $\begin{array}{l}\text { Food } \\
\text { consumed }\end{array}$ & Frequency & $n=139$ & $\%$ \\
\hline \multirow[t]{3}{*}{ Milk } & Always ( $>2$ times per week) & 6 & 5.2 \\
\hline & $\begin{array}{l}\text { Rarely (twice or less per } \\
\text { week) }\end{array}$ & 13 & 9.4 \\
\hline & Almost never & 120 & 85.4 \\
\hline \multirow[t]{3}{*}{ Tea } & Always ( $>2$ times per week) & 109 & 78.4 \\
\hline & $\begin{array}{l}\text { Rarely (twice or less per } \\
\text { week) }\end{array}$ & 14 & 10.1 \\
\hline & Almost never & 16 & 11.5 \\
\hline \multirow{3}{*}{$\begin{array}{l}\text { Coconut } \\
\text { food }\end{array}$} & Always ( $>2$ times per week) & 19 & 13.7 \\
\hline & $\begin{array}{l}\text { Rarely (twice or less per } \\
\text { week) }\end{array}$ & 59 & 42.0 \\
\hline & Almost never & 61 & 43.9 \\
\hline \multirow[t]{3}{*}{ Fruit } & Always ( $>2$ times per week) & 45 & 32.4 \\
\hline & $\begin{array}{l}\text { Rarely (twice or less per } \\
\text { week) }\end{array}$ & 67 & 48.2 \\
\hline & Almost never & 27 & 19.4 \\
\hline \multirow[t]{3}{*}{ Meat } & Always ( $>2$ times per week) & 16 & 11.5 \\
\hline & $\begin{array}{l}\text { Rarely (twice or less per } \\
\text { week) }\end{array}$ & 37 & 26.6 \\
\hline & Almost never & 81 & 61.9 \\
\hline \multirow[t]{3}{*}{ Fatty meat } & Always (>2 imes per week) & 18 & 12.9 \\
\hline & $\begin{array}{l}\text { Rarely (twice or less per } \\
\text { week) }\end{array}$ & 29 & 20.9 \\
\hline & Almost never & 92 & 66.2 \\
\hline \multirow[t]{3}{*}{ Egg } & Always ( $>2$ times per week) & 14 & 10.1 \\
\hline & $\begin{array}{l}\text { Rarely (twice or less per } \\
\text { week) }\end{array}$ & 78 & 56.1 \\
\hline & Almost never & 47 & 33.8 \\
\hline \multirow[t]{3}{*}{ Vegetable } & Always (>2 times per week) & 34 & 24.5 \\
\hline & $\begin{array}{l}\text { Rarely (twice or less per } \\
\text { week) }\end{array}$ & 41 & 29.5 \\
\hline & Almost never & 64 & 46.0 \\
\hline \multirow[t]{3}{*}{ Garlic } & Always (>2 times per week) & 54 & 38.9 \\
\hline & $\begin{array}{l}\text { Rarely (twice or less per } \\
\text { week) }\end{array}$ & 62 & 44.6 \\
\hline & Almost never & 23 & 16.5 \\
\hline
\end{tabular}

Table 5. Relationship of education to some risk factors among skin cancer cases

\begin{tabular}{|c|c|c|c|c|}
\hline \multirow{2}{*}{$\begin{array}{l}\text { Factors } \\
\text { Determinants }\end{array}$} & \multicolumn{2}{|c|}{ Education } & \multirow[b]{2}{*}{ Total } & \multirow[b]{2}{*}{$\mathbf{X}^{2}$} \\
\hline & $\begin{array}{l}\text { Elementa } \\
\text { ry school }\end{array}$ & $\begin{array}{l}\text { Juiar \& } \\
\text { Serior HS. }\end{array}$ & & \\
\hline \multicolumn{5}{|l|}{ Occupation } \\
\hline Outside & 62 & 7 & 69 & \\
\hline Inside & 47 & 23 & 70 & $9.29 * * * *$ \\
\hline Test for trend : & 2.29 & $8.31+4+*$ & & - \\
\hline \multicolumn{5}{|l|}{ Smoking habit } \\
\hline Active smoker & 27 & 5 & 32 & \\
\hline Ex smoker & 14 & 8 & 22 & 2.04 \\
\hline No smoking & 68 & 17 & 85 & 0.08 \\
\hline Test for trend : & 0.00 & 0.01 & & \\
\hline \multicolumn{5}{|l|}{$\begin{array}{l}\text { Exposed to } \\
\text { cigarette }\end{array}$} \\
\hline Yes & 42 & 20 & 62 & \\
\hline No & 67 & 10 & 77 & $8.72 * * * *$ \\
\hline Test for trend : & 1.63 & $5.91^{* *}$ & & \\
\hline \multicolumn{5}{|l|}{$\begin{array}{l}\text { Using long } \\
\text { sleeve }\end{array}$} \\
\hline Yes & 33 & 26 & 59 & \\
\hline ivo & 76 & 4 & 80 & $32.98^{* * * * *}$ \\
\hline Test for trend : & $6.61^{* *}$ & $24.01 * * * * *$ & & \\
\hline \multicolumn{5}{|l|}{ Fat consumption } \\
\hline High & 9 & 9 & 18 & \\
\hline Moderate & 16 & 13 & 29 & 0.42 \\
\hline Low & 84 & 8 & 92 & $22.95^{* * * * *}$ \\
\hline Test for trend : & $5.202^{* *}$ & $18.90^{* * *+4}$ & & \\
\hline \multicolumn{5}{|c|}{ Protein consumption } \\
\hline High & 4 & 12 & 16 & \\
\hline Moderate & 21 & 16 & 37 & $5.885^{* *}$ \\
\hline Low & 84 & 2 & 86 & $66.46^{* * * * * *}$ \\
\hline Test for trend : & $12.04^{* * *}$ & 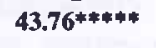 & & \\
\hline \multicolumn{5}{|l|}{$\begin{array}{l}\text { Vegetable/ fruit } \\
\text { consumption }\end{array}$} \\
\hline High & 22 & 23 & 45 & \\
\hline Moderate & 60 & 7 & 67 & $24.82 * * * * *$ \\
\hline Low & 27 & 0 & 27 & $21.25^{* * * * *}$ \\
\hline Test for trend : & $6.69 * * *$ & $22.51 * * * * *$ & & \\
\hline
\end{tabular}

* significant difference at $p<0.05$

** significant difference at $\mathrm{p}<0.025$

*** significant difference at $p<0.01$

**** significant difference at $\mathrm{p}<0.005$

***** significant difference at $\mathrm{p}<0.001$

Table 6 shows the relationship between occupation and the same some risk factors as in Table 5. The Chisquare test did not show a significant relationship between occupation with those factors, except vegetable/ fruit consumption. The test for trend also showed that there is no significant trend in outdoor/ indoor group, except for vegetable consumption. 
Table 6. Relationship of occupation to some risk factors among skin cancer

\begin{tabular}{|c|c|c|c|c|}
\hline \multirow{2}{*}{$\begin{array}{l}\text { Determingant } \\
\text { Factors }\end{array}$} & \multicolumn{2}{|c|}{ Occupation } & \multirow[t]{2}{*}{ Total } & \multirow[t]{2}{*}{$x^{2}$} \\
\hline & Outdoor & Indoor & & \\
\hline \multicolumn{5}{|l|}{ Using long Sleeve } \\
\hline Yes & 33 & 26 & 59 & \\
\hline No & 36 & 44 & 80 & 1.22 \\
\hline Test for trend : & 0.82 & 0.81 & & \\
\hline \multicolumn{5}{|l|}{ Fat consumption } \\
\hline High & 5 & 13 & 18 & \\
\hline Moderate & 16 & 13 & 29 & $4.57^{*}$ \\
\hline Low & 48 & 44 & 92 & $4.63 *$ \\
\hline Test for trend : & 1.12 & 1.10 & & \\
\hline \multicolumn{5}{|l|}{$\begin{array}{l}\text { Protein } \\
\text { consumption }\end{array}$} \\
\hline High & 8 & 8 & 16 & \\
\hline Moderate & 16 & 21 & 37 & 0.02 \\
\hline Low & 45 & 41 & 86 & 0.53 \\
\hline Test fur trend : & 0.15 & 0.15 & & \\
\hline \multicolumn{5}{|l|}{$\begin{array}{l}\text { Vegetables/ } \\
\text { fruits consumption }\end{array}$} \\
\hline High & 16 & 29 & 45 & \\
\hline Moderate & 33 & 34 & 67 & 2.65 \\
\hline Low & 20 & 7 & 27 & \\
\hline Test for trend : & $4.84^{*}$ & $4.77^{*}$ & & $11.615^{* * * * *}$ \\
\hline
\end{tabular}

* significant difference at $\mathrm{p}<0.05 ; * * * * *$ significant difference at $\mathrm{p}<0.001$

Analysis of BCC and SCC was shown in Table 7. The number of BCC was 3 times higher than SCC $(92$ vs 33). BCC was found more frequent in male than female with younger onset of age, has been less exposure to UV compared to SCC. There is no difference of percentage in fat/ protein /vegetable consumption between BCC and SCC. From the test for trend, both in $\mathrm{BCC}$ and SCC no significant result were found in demographic (gender, age, occupation), and nutrition (consumption of fat, protein \& vegetable) risk factors.

\section{DISCUSSION}

This paper is based on the $50 \%$ of the actual target of cases in tie case-control study on skin cancer. Some difficulties arises in form of getting control for old cases (more than 70 years old) and having a qualified food pattern in the last 5 years. In this study, skin cancer was equally distributed among males and females. This result differs from other study, where males were more at risk compared to women. ${ }^{4}$ Assumption that women in Indonesia had been more exposed to the UV is not supported by our data. The health seeking behavior in women to find immediate help and the location of skin cancer in the face probably could explain this result.
Table 7. Distribution of skin cancer type by age, gender, education, occupation and dietary consumption

\begin{tabular}{|c|c|c|c|c|}
\hline $\begin{array}{l}\text { Factors } \\
\text { determinants }\end{array}$ & $\begin{array}{c}\mathrm{BCC} \\
(n=92)\end{array}$ & $\begin{array}{c}\text { SCC } \\
(n=33)\end{array}$ & Total & $x^{2}$ \\
\hline \multicolumn{5}{|l|}{ Gender } \\
\hline Male & 38 & 19 & 57 & \\
\hline Female & 54 & 14 & 68 & $3: 29$ \\
\hline Test for trend : & 0.68 & 1.91 & & \\
\hline \multicolumn{5}{|l|}{ Age } \\
\hline$<40$ years & 5 & 4 & 57 & \\
\hline $40-50$ years & 16 & 7 & 68 & $9.61 * \div * *$ \\
\hline $51-60$ years & 31 & 6 & 37 & $20.65^{* * * * *}$ \\
\hline$>60$ years & 40 & 16 & 56 & $13.98^{* * * * *}$ \\
\hline Test for trend : & 0.11 & 0.29 & & \\
\hline \multicolumn{5}{|l|}{ Education } \\
\hline Senior HS & 15 & 6 & 21 & \\
\hline Junior HS & 8 & 5 & 13 & 0.05 \\
\hline Elementary $S$ & 69 & 22 & 91 & 0.49 \\
\hline Test for trend : & $19.07 * * * * * *$ & 0.32 & & \\
\hline \multicolumn{5}{|l|}{ Occupation } \\
\hline Indoor & 52 & 12 & 64 & \\
\hline Outdoor & 40 & 21 & 61 & 3.18 \\
\hline Test for trend : & 1.04 & 2.91 & & \\
\hline \multicolumn{5}{|l|}{ Fat consumption } \\
\hline High & 11 & 4 & 15 & \\
\hline Moderate & 21 & 7 & 28 & 0.24 \\
\hline Low & 60 & 22 & 82 & 0.09 \\
\hline Test for trend : & 0.00 & 0.00 & & \\
\hline \multicolumn{5}{|c|}{ Protein consumption } \\
\hline High & 10 & 2 & 12 & \\
\hline Moderate & 28 & 9 & 37 & 0.02 \\
\hline Low & 54 & 22 & 76 & 0.29 \\
\hline Test for trend : & 0.24 & 0.66 & & \\
\hline \multicolumn{5}{|l|}{$\begin{array}{l}\text { Vegetable/ frult } \\
\text { consumption }\end{array}$} \\
\hline High & 34 & 14 & 48 & \\
\hline Moderate & 42 & 14 & 56 & 0.49 \\
\hline Low & 16 & 5 & 21 & 0.56 \\
\hline Test for trend: & 0.00 & 0.37 & & \\
\hline
\end{tabular}

**** significant difference at $p<0.005$;

****** significant difference at $\mathrm{p}<0.001$

Almost $75 \%$ cases were more than 50 years old and the increase trend of skin cancer with age has been noted. This observation is in line with the effect of the more or less continuous exposure to the sun throughout life.

Sun exposure in many studies has been shown to be the significant risk factor for skin cancer. Sun exposure in this study was tested in respect to the site of work (outdoor or indoor) and using long sleeve. In this study there was no difference in site work among skin cases, and also there was no relationship between the site of work and using long sleeve. One hypothesis which could explain this situation was that the exposure was received during the early years (before 10 years old), not in the adult phase. ${ }^{8-9}$ 
Another interesting result was that education seemed to have a greater effect on some risk factors than occupation. Education had a significant relationship with exposure to cigarette smoke, using long sleeve and food pattern intake of fat/ protein and vegetables/ fruits. Low fat diet has been shown to be a negative risk factor for many cancers, including skin cancer. ${ }^{10}$ However, these factors showed no significant relationship with occupation in our study. Some studies also did not reveal the relationship of occupation indoor and outdoor, because there were other factors which also had a role in skin cancer such as skin type. Indonesian with skin type 4 or 5 is assumed to have a protective reaction to solar radiation. Since $78.4 \%$ cases come from lower educational level it is understandable that these cases will have a less protective attitude to prevent skin cancer.

The test for trend in this study confirmed some of the general findings. The data showed that in the higher educated group highly significant relationship exist in occupation, exposure to cigarette, using long sleeve, and consumption of fat/protein/vegetables.

\section{Acknowledgement}

We appreciate the International Cancer Research Grant system, Monbusho, Japan and the Dean, Faculty of Medicine, University of Indonesia, Jakarta for his approval of the Japan-Indonesia Collaborative Study, No. 845/PT.02.H4.FK/E/97. This work has been supported by the Grant No. 09042004, under the Ministry of Education, Science, Sports and Culture, Government of Japan and was partly supported by the Indonesian Cancer Foundation, the Jakarta International Cancer Conference Fund and the Terry Fox Foundation, Canada. We would also thank the Director of Dr. Cipto Mangunkusumo National Central General Hospital, for his technical support to finish this work. We are debtful for excellent assistance of Ms. Ros, Titien, Yeni and Mimin, the clinical and public health nurses in data collection.

\section{REFERENCES}

1. Cornain S, Mangunkusumo R, Nasar IM, Prihartono J. Ten most frequent cancers in Indonesia. Pathology based cancer registry data of 1988 - 1992. In: Cancer Registry in Indonesia. National Cancer Registry Center Jakarta Coordinating Board, 1997.

2. Sarjadi. Cancer Incidence 1985-1989 in Semarang, Indonesia. Indonesian Cancer Society, 1990.
3. Tjarta A, Kanoko M, Mangunkusumo R. Malignant melanoma and malignant epidermal tumor in Jakarta. Relative frequency and some histopathological aspects. Presented in the $2^{\text {nd }}$ Congress Asia-Pacific Association Societies of Pathologist, Feb 20-23, 1991, ManilaPhillipine.

4. Ohno Y, Ichihashi M, Ueda M, Munakata N, Cornain S. Prevalence study on sun protection behaviors/ practices in several representative population samples in Indonesia. Med J Indones 2000; 9:112-7.

5. Naruse K, Suzuki T, Harada S, Imaizumi K, Wadabayashi $N$, Watanabe S, Ichihashi $M$. Prevalence rate of non melanoma skin cancer on sun exposed areas in Japanese. In: Berkel HJ, Kresno SB, Tjarta A, et al, editors. Proceedings of Jakarta International Cancer Conference 1995. Jakarta: Indonesian Society of Oncology-OC JICC 1995, 1995: 443-53.

6. Suzuki T, Ueda M, Ogata K, Horikoshi T, Munakata N, Ichihashi $M$. Doses of solar ultra violet radiation correlate with skin cancer rates in Japan. Kobe J Med Sci 1996; 42: $375-88$.

7. Naruse K, Ueda M, Nagano T, Suzuki T, Harada S, Intaizumi $K$, Watanabe S, Ichihashi $M$. Prevalence of Actinic keratosis in Japan. Japan J Dermatol Sci 1997; 15: $183-7$.

8. Thomson SC, Jolley D, Marks R. Reduction of solar keratosis by regular sun screen use. N Engl J Med 1993; 329: 1147-51.

9. Nagano T, Ueda M, Suzuki T, Naruse K, Nakamura T, Taguchi M, Araki K, Nakagawa H, Hayashi K, Watanabe , S, Ichihashi M. Skin cancer screening in Okinawa, Japan. Japan J Dermatol Sci 1999 (in press).

10. Homer S Black, John I Thorby, John E Wolf Jr, Leonard H, Golberg J, Alan Herd, Theodore R, Suzanne Bruce, Jaime A, Tschen, Lynne W Scott, Suzanne Jaax, John P Foreyt, Brenda Reusser: Evidence that a low fat diet reduces the occurance of Non Melanoma Skin Cancer. Int J Cancer 1995; 62: 165-9.

11. Kricker A, Armstrong BK, English DR. Sun exposure and non-melanocytic skin cancer. Cancer Causes and Control 1994; 5: 367-92.

12. Grodstein F, Speizer FE, Hunter DJ. A prospective study on incident squamous cell carcinoma of the skin in the Nurses Health Study. J Natl Cancer Inst 1995; 87: 1061-6.

13. Weinstock MA. The epidemic of squamous cell carcinoma. JAMA 1989; 262: 2138-40.

14. Karagas MR, Stukel TA, Greenberg R, Baron JA, Mott LA, Stern RS. Risk of subsequent basal cell carcinoma and squamous cell carcinoma of the skin among patients with prior skin cancer. JAMA 1992; 267: 3305-10.

15. Sankaranarayanan R, Mathew B. Retinoids as cancer preventive agents. In: Stewart BW McCregor and Kleinhues $\mathrm{P}$, editors. Principles of chemoprevention. IARC Scientific Publications 1996: 49-59.

16. Ley RD, Reeve VE. Chemoprevention of Ultra Violet radiation-induced skin cancer. Environ Health Perspect 1997: 981-4 (supplement).

17. Suarez Varella MMM, Gonzales AL, Caraco EF. Nonmelanoma skin cancer: A case control study on risk factor and protective measures. J Environ Pathol, Toxicol \& Oncol 1996; 15: 255-61. 